\title{
RELATIVIZAÇÃO DA COISA JULGADA INCONSTITUCIONAL EM FACE DA SEGURANÇA JURÍDICA E DA JUSTIÇA DAS DECISÕES JUDICIAIS ${ }^{1}$
}

\author{
RELATIVIZATION OF UNCONSTITUTIONAL RES JUDICATA IN FACE OF LEGAL \\ CERTAINTY AND JUSTICE OF JUDGMENTS
}

\section{Elis Regina Sousa Miranda*}

Submissão: 08/06/2013

Aceito para Publicação: 31/07/2013

\begin{abstract}
Sumário: Introdução. 1 Da Constituição Federal. 1.1 Controle de constitucionalidade dos atos judiciais. 1.2 Tratamento constitucional da coisa julgada. 2. Confronto entre segurança jurídica e justiça. 2.1 Breve histórico da relativização. 2.2 Requisitos para a relativização. 2.3 Críticas à teoria da relativização. 3. Do vício da inconstitucionalidade. 3.1 Análise do vício da inconstitucionalidade sob a ótica da teoria dos atos jurídicos. 3.2 Vício da inconstitucionalidade e eficácia sanatória geral da coisa julgada. 4. Instrumentos da relativização 4.1 Instrumentos da relativização típica. 4.2 Instrumentos da relativização atípica. 4.3 Análise sob a ótica do ordenamento de lege lata. 4.4 Proposta de lege ferenda. Considerações finais. Referências.
\end{abstract}

Resumo: Durante muito tempo a coisa julgada foi concebida como um instituto intangível, somente passível de relativização nas hipóteses de ação rescisória. No entanto, este instituto, embora indispensável para a segurança jurídica, passou a ser contestado devido a decisões que acarretavam evidentes injustiças e/ou inconstitucionalidades. Nesse contexto, o presente artigo pretendeu sistematizar as teses existentes acerca da relativização da coisa julgada inconstitucional, identificando os posicionamentos favoráveis e desfavoráveis. Ademais, objetivou-se identificar se o ordenamento jurídico atual apresenta mecanismos capazes de solucionar o problema. Caso contrário, objetivou-se analisar a viabilidade das teses de

\footnotetext{
${ }^{1}$ Artigo extraído da Monografia apresentada ao curso de Direito da Universidade Federal de Viçosa como requisito para obtenção do título de bacharel em Direito e aprovada pela banca examinadora composta pelo Orientador Gabriel Pires e pelos Professores Gláucio Inácio da Silveira e Regel Antônio Ferrazza, em 25 de abril de 2013.

* Universidade Federal de Viçosa.
} 
relativização atípica e buscar uma solução que concilie os ideais de segurança jurídica e justiça.

Palavras-chave: Coisa julgada; Relativização; Segurança jurídica; Justiça; Constituição Federal.

Abstract: For a long time the res judicata was conceived as an intangible institute only capable of being relativized in cases of rescission action. However, this institute, although indispensable for legal certainty, came to be challenged due to decisions that entailed obvious injustices and/or unconstitutionalities. In this context, this study aimed to systematize the existing theories about the relativization of unconstitutional res judicata, identifying favorable and unfavorable positions. Furthermore, this study aimed to identify whether the current law has mechanisms to solve the problem. Otherwise, it aimed to examine the feasibility of the atypical relativization theses and to seek a solution that reconciles the ideals of legal certainty and justice.

Keywords: Res judicata; Relativization; Legal certainty; Justice; Federal constitution.

\section{INTRODUÇÃO}

As transformações no direito processual civil moderno, especialmente no que tange ao denominado processo civil de resultados, trouxeram consigo exigências de efetividade e de justiça. ${ }^{2}$ A própria noção de processo adquiriu novos contornos, passando a pressupor a noção de resultado justo, compatível com a Constituição Federal e o mais próximo possível da verdade real. $^{3}$

\footnotetext{
2 "O direito processual moderno é um sistema orientado à construção de resultados justos. A ideologia do processualista contemporâneo, conhecida como processo civil de resultados, leva à necessária revisão de diversos conceitos que pareciam firmemente estabelecidos no panteão dos dogmas jurídicos.” CÂMARA, Alexandre Freitas. Relativização da coisa julgada material. In: NASCIMENTO, Carlos Valder do (Coord.). Coisa julgada inconstitucional. 4. ed. Rio de Janeiro: América Jurídica, 2003, p. 202.

3 "O Direito Processual Civil mudou e a busca da verdade real, como meio de se alcançar a justiça e concretizar o anseio do justo processo legal, é uma exigência de tempos modernos. (grifo do autor)” THEODORO JÚNIOR, Humberto; FARIA, Juliana Cordeiro de. A coisa julgada inconstitucional e os instrumentos processuais para o seu controle. In: NASCIMENTO, Carlos Valder do (Coord.), op. cit., p. 91. "A propósito do problema da obtenção da verdade no processo (ainda que adjetivada como verdade processual, já que a verdade no processo sempre se resolve num juízo de verossimilhança), impende observar desde logo que a sua colocação como um dos objetivos ideais da prova judiciária oferece-se como uma condição insuprimível para que o processo cumpra a contento o seu desiderato maior de lograr a justiça do caso decidendo". MITIDIERO, Daniel. Colaboração no processo civil: pressupostos sociais, lógicos e éticos. 2 ed. São Paulo: Editora Revista dos Tribunais, 2011, p. 108.
} 
Nesse contexto, doutrina e tribunais, ao se depararem com situações em que a manutenção da coisa julgada colidia com o senso de justiça social, começaram a defender uma mitigação do instituto. Assim, embora seja inegável a relevância da coisa julgada para a manutenção da estabilidade da ordem jurídica, vislumbrou-se a necessidade de compatibilizála com outros direitos constitucionalmente previstos e com novos anseios sociais. No Brasil, referida tese ganhou maior força no ano de 2011, quando o STF (Supremo Tribunal Federal) reconheceu a possibilidade de relativização da coisa julgada no caso de ações de estado. ${ }^{4}$

Diante dessas transformações, o presente artigo pretende analisar a temática da relativização da coisa julgada inconstitucional. A escolha do tema deve-se à importância do instituto da coisa julgada e de todas as suas implicações no ordenamento jurídico brasileiro. Ao mesmo tempo em que é preciso garantir a definitividade e imutabilidade das decisões judiciais, em prol da segurança jurídica e da estabilidade das relações sociais, deve-se assegurar aos jurisdicionados que as decisões sejam justas e compatíveis com a Constituição Federal.

Inegável é a relevância do debate, envolvendo questionamentos vários, como a própria função do Direito no âmbito das relações sociais; o fundamento de validade das decisões judiciais; o alcance da norma contida no artigo $5^{\circ}$, XXXVI, da Constituição Federal, e a ponderação entre o anseio de legitimidade da ordem jurídica e a necessidade de se preservar a segurança.

O presente artigo pretende, primeiramente, promover uma sistematização das diversas teses existentes acerca da relativização da coisa julgada inconstitucional, identificando os posicionamentos favoráveis e desfavoráveis, os requisitos e os instrumentos apontados pela doutrina. Posteriormente, pretende-se verificar se a legislação processual civil de lege lata ${ }^{5}$ já solucionou o problema da sentença inconstitucional transitada em julgado. Caso a resposta seja negativa, pretende-se analisar a viabilidade da relativização atípica da coisa julgada inconstitucional e buscar uma solução que concilie os ideais de segurança jurídica e justiça.

Por derradeiro, faz-se necessário registrar duas observações de ordem terminológica. A primeira delas diz respeito a uma advertência feita por José Carlos Barbosa Moreira quanto ao termo "relativização". Segundo o autor, referido termo transmite a ideia de ser a coisa julgada absoluta, o que, evidentemente, não é verdade, tendo em vista as hipóteses de ação

\footnotetext{
${ }^{4}$ Cf. BRASIL. Supremo Tribunal Federal. Recurso Extraordinário n. 363.889/DF. Recorrentes: Ministério Público do DF e D.G.S. Recorrido: G.F.R. Relator: Dias Toffoli. Brasília, 02 de junho de 2011.

${ }^{5}$ A expressão latina "de lege lata" significa "da lei existente" e se contrapõe à expressão "de lege ferenda", que significa "da lei a ser criada".
} 
rescisória há muito previstas no ordenamento jurídico. ${ }^{6}$ Desse modo, faz-se necessário assinalar que, apesar da inadequação do termo, ele é utilizado pela maioria dos doutrinadores com o intuito de referirem-se à possibilidade de relativização da coisa julgada independentemente dos instrumentos legalmente previstos.

Outros doutrinadores, porém, a fim de evitarem o equívoco que o termo poderia causar, utilizam a expressão "relativização atípica” com o intuito de referirem-se exclusivamente às hipóteses de relativização da coisa julgada além daquelas tipificadas na lei. No presente artigo, objetivando-se simplificar e seguir a terminologia da maioria dos doutrinadores, utilizar-se-á, em diversos momentos, somente o termo "relativização”, o qual deve ser compreendido abstraindo-se as hipóteses legais que já ensejam a revisão da coisa julgada.

A segunda observação diz respeito à expressão “coisa julgada inconstitucional”. Ela é utilizada pela maioria dos doutrinadores de um modo geral e indiscriminado. Outros, porém, diferenciam “coisa julgada inconstitucional” de “coisa julgada injusta inconstitucional”, utilizando a primeira expressão para referirem-se à coisa julgada que abarca sentenças de mérito que tenham como fundamento uma norma declarada inconstitucional pelo STF e utilizando a segunda expressão para referirem-se à coisa julgada que acoberta sentenças que ofendem diretamente valores constitucionais essenciais ao Estado Democrático de Direito. Pelas mesmas razões expostas em relação à preferência quanto ao termo “relativização”, no presente artigo, não se adotará a distinção acima citada, utilizando-se somente a expressão “coisa julgada inconstitucional”.

\section{DA CONSTITUIÇÃO FEDERAL}

\subsection{Controle de constitucionalidade dos atos judiciais}

Conforme a teoria desenvolvida por Hans Kelsen, o Direito organiza-se em uma estrutura hierárquica, segundo a qual as normas jurídicas situam-se em níveis distintos, de modo que as inferiores precisam fundamentar sua validade nas superiores. Essa linha de

\footnotetext{
${ }^{6}$ Cf. MOREIRA, José Carlos Barbosa. Temas de direito processual civil (nona série). São Paulo: Saraiva, 2007, p. 235-236.
} 
regressão às normas mais superiores do sistema jurídico conduz, inevitavelmente, à última norma positiva, a Constituição Federal. ${ }^{7}$

Sendo a Constituição Federal o fundamento de validade de todo o ordenamento, conclui-se que nenhum ato jurídico pode subsistir validamente se estiver contaminado pelo vício da inconstitucionalidade. Com efeito, a supremacia da Constituição não se dá somente em relação aos atos normativos, abrangendo, obviamente, as decisões proferidas pelo Poder Judiciário.

Apesar dessa concepção estar consolidada atualmente, durante muitos anos inexistiu qualquer preocupação quanto ao controle de constitucionalidade dos atos judiciais, de modo que as atenções sempre se detiveram nos atos legislativos desconformes com a Constituição. Assim, de acordo com Humberto Theodoro Júnior e Juliana Cordeiro de Faria, tal cenário deu ensejo à equivocada ideia de intangibilidade das decisões judiciais. ${ }^{8}$

Acerca dessa questão, relevante é a lição de Paulo Otero, o qual ensina que se a lei não é imune ao controle de constitucionalidade, as decisões judiciais também não haveriam de ser. ${ }^{9}$ Desse modo, embora comumente a referência ao controle de constitucionalidade seja feita somente em relação às leis, não se pode olvidar que os atos dos três Poderes - Executivo, Legislativo e Judiciário - só poderão subsistir validamente se estiverem em conformidade com a Constituição Federal. ${ }^{10}$

\subsection{Tratamento constitucional da coisa julgada}

A única alusão feita pela Constituição Federal à coisa julgada está contida no artigo $5^{\circ}$, XXXVI, o qual dispõe que "a lei não prejudicará o direito adquirido, o ato jurídico perfeito e a coisa julgada”. O alcance da referida norma é objeto de discussão doutrinária, dando ensejo a duas correntes.

A primeira corrente, na qual se enquadra o doutrinador Paulo Roberto de Oliveira Lima, defende que a proteção constitucional da coisa julgada não impede a existência de

\footnotetext{
${ }^{7}$ Cf. KELSEN, Hans. Teoria Pura do Direito. 6. ed. São Paulo: Martins Fontes, 1998, p. 246.

${ }^{8}$ Nesse sentido, dissertam os doutrinadores: "Com efeito, institucionalizou-se o mito da impermeabilidade das decisões judiciais, isto é, de sua imunidade a ataques, ainda que agasalhasem inconstitucionalidade, especialmente após operada a coisa julgada e ultrapassado, nos variados ordenamentos, o prazo para a sua impugnação. A coisa julgada, neste cenário, transformou-se na expressão máxima a consagrar os valores de certeza e segurança perseguidos no ideal do Estado de Direito. Consagra-se, assim, o princípio da intangibilidade da coisa julgada, visto, durante vários anos, como dotado de caráter absoluto". THEODORO JÚNIOR, Humberto; FARIA, Juliana Cordeiro de, op. cit., p. 72.

${ }^{9}$ Cf. OTERO, Paulo. Ensaio sobre o caso julgado inconstitucional. Lisboa: Lex, 1993, p. 10.

${ }^{10}$ Cf. BARROSO, Luís Roberto. O controle de constitucionalidade no direito brasileiro. 4. ed. São Paulo: Saraiva, 2009, p. 2.
} 
remédio jurídico-processual hábil a desconstituí-la, posto que tão somente protege o instituto em face de alterações legislativas subsequentes. ${ }^{11}$

A segunda corrente, na qual se enquadram os doutrinadores Alexandre Freitas Câmara e Cândido Rangel Dinamarco ${ }^{12}$, defende que o tratamento constitucional destinado ao instituto da coisa julgada não se limita a garantir a sua proteção em face da retroatividade da lei, abrangendo todo instrumento jurídico que venha a prejudicá-lo. No entanto, Câmara adverte que a coisa julgada, embora seja uma garantia constitucional, não é absoluta e imune a qualquer espécie de relativização. ${ }^{13}$

Percebe-se que o tratamento constitucional da coisa julgada constitui um tema bastante controvertido na doutrina processual brasileira, sendo que o entendimento da norma consagrada no artigo 5, XXXVI, da Constituição Federal, influi diretamente na possibilidade ou não de relativização.

Nesse contexto, entendemos que, diante da proteção constitucional da coisa julgada no rol dos direitos e garantias fundamentais e diante do reconhecimento do Estado Democrático de Direito - o qual tem como base a segurança jurídica - como um princípio fundamental da república, não há como negar ao referido instituto o caráter de cláusula pétrea, conforme disposto no artigo 60 , $\S 4^{\circ}$, IV. ${ }^{14}$

Sendo a coisa julgada uma cláusula pétrea, entendemos que ela merece proteção não apenas em face das leis, mas também em face das decisões judiciais. Com efeito, tanto os legisladores como os julgadores estão proibidos de violar a coisa julgada, até mesmo porque, tendo em vista o princípio da separação e harmonia dos poderes, previsto no artigo $2^{\circ}$, da Constituição Federal, não há motivos para se estabelecer um tratamento diferenciado que beneficie o Poder Judiciário.

\footnotetext{
${ }^{11}$ Paulo Roberto de Oliveira Lima considera que a proteção constitucional conferida à coisa julgada é mais tímida do que se supõe, de modo que não há impedimentos para a existência de restrições e de instrumentos de revisão dos julgados, pois, se assim fosse, a ação rescisória e a revisão criminal seriam institutos inconstitucionais. Para o autor, a Constituição Federal consagra a coisa julgada como uma das facetas do princípio da não surpresa ou irretroatividade da lei. Cf. LIMA, Paulo Roberto de Oliveira. Contribuição à teoria da coisa julgada. São Paulo: RT, 1997, p. 86.

12 Cândido Rangel Dinamarco defende que a proteção constitucional da coisa julgada não se destina exclusivamente ao legislador, de modo que o constituinte disse menos do que queria: "Por força da coisa julgada, não só o legislador carece de poderes para dar nova disciplina a uma situação concreta já definitivamente regrada em sentença irrecorrível, como também os juízes são proibidos de exercer a jurisdição outra vez sobre o caso e as partes já não dispõem do direito de ação ou de defesa como meios de voltar a veicular em juízo a matéria já decidida.” DINAMARCO, Cândido Rangel. A Nova Era do Processo Civil. São Paulo: Malheiros, 2003, p. 245.

${ }^{13}$ Cf. CÂMARA, Alexandre Freitas, op. cit., p. 193.

${ }^{14}$ Cf. GOÉS, Gisele Santos Fernandes. A "Relativização" da Coisa Julgada: exame crítico (exposição de um ponto de vista contrário). Revista de Processo, São Paulo, ano 31, n. 135, p. 249-265, maio de 2006.
} 
Todavia, ressalta-se que o referido entendimento não inviabiliza toda e qualquer alteração da disciplina processual acerca da coisa julgada, uma vez que o artigo 60 , $\S 4^{\circ} \mathrm{c} / \mathrm{c}$ artigo $60, \S 4^{\circ}$, IV, são claros ao dispor que não será objeto de deliberação a proposta de emenda tendente a abolir os direitos e garantias individuais. Assim, inicialmente, é perfeitamente possível uma eventual alteração legislativa do artigo 485, do Código de Processo Civil, desde que ela não ocasione a destruição ou profunda mudança de identidade do instituto da coisa julgada.

\section{CONFRONTO ENTRE SEGURANÇA JURÍDICA E JUSTIÇA}

\subsection{Breve histórico da relativização}

O movimento de relativização da coisa julgada além das hipóteses autorizadoras da ação rescisória foi motivado por algumas decisões que, conquanto tivessem sido abarcadas pelo trânsito em julgado, continham uma evidente injustiça e/ou inconstitucionalidade.

Isso ocorreu, principalmente, nas demandas expropriatórias em que se buscava uma justa indenização e nas demandas de investigação de paternidade. Nas primeiras, o sentimento de evidente injustiça ora decorreu da própria interpretação do termo “justa indenização" ${ }^{15}$, ora decorreu da constatação fática de estar sendo imposta ao erário uma dupla cobrança pelo imóvel desapropriado, o qual já pertencia ao órgão expropriante. ${ }^{16}$

Nas demandas investigatórias de paternidade, ${ }^{17}$ o sentimento de injustiça e, de certa forma, de descrédito em relação à decisão judicial, emanava da superveniente realização de um exame de DNA, o qual apontava uma paternidade diversa daquela que havia sido reconhecida pelo Poder Judiciário.

\footnotetext{
${ }^{15}$ Cf. BRASIL. Superior Tribunal de Justiça. Recurso Especial n. 765.566/RN. Recorrente: Instituto Nacional de Colonização e Reforma Agrária - INCRA. Recorrido: Estado do RN. Relator: Luiz Fux. Brasília, 19 de abril de 2007.

${ }^{16}$ Cf. BRASIL. Superior Tribunal de Justiça. Recurso especial n. 240.712/SP. Recorrente: Fazenda do Estado de SP. Recorridos: James Ross e outros. Relator: José Delgado. Brasília, 15 de fevereiro de 2000.

${ }^{17}$ Em relação às demandas de investigação de paternidade, cumpre registrar que tramita na Câmara dos Deputados o Projeto de Lei n. 6960/02, o qual prevê, no artigo 1.606, § $2^{\circ}$, que referidas demandas somente ficarão abarcadas pelo trânsito em julgado após realização do exame de DNA, ressalvada a hipótese de recusa à submissão ao referido exame pericial. Cf. BRASIL. Congresso. Câmara dos Deputados. Projeto de lei n. $6960 / 02$.
} 
A partir de então, além dos tradicionais instrumentos de revisão da coisa julgada, a doutrina passou a vislumbrar e instituir meios atípicos de relativização, visando desconstituir a coisa julgada inconstitucional.

\subsection{Requisitos para a relativização}

A doutrina favorável à relativização defende que a coisa julgada, apesar de constituir um importante instrumento de tutela da segurança jurídica, não é, em si, um valor absoluto. A ideologia desse movimento é muito bem sintetizada na seguinte frase de Cândido Rangel Dinamarco: "não é legítimo eternizar injustiças a pretexto de evitar a eternização de incertezas. (grifo do autor)" 18

Entre os defensores da tese da relativização da coisa julgada inconstitucional, constatamos a existência de três correntes no que tange à formulação de requisitos. $\mathrm{Na}$ primeira corrente, enquadramos o ministro José Augusto Delgado ${ }^{19}$ e a doutrinadora Maria Berenice Dias ${ }^{20}$, os quais consideram que a injustiça da decisão judicial constitui requisito suficiente para ensejar a relativização da coisa julgada.

Na segunda corrente, enquadramos os doutrinadores Alexandre Freitas Câmara ${ }^{21}$, Humberto Theodoro Júnior e Juliana Cordeiro de Faria ${ }^{22}$, os quais, embora favoráveis à relativização da coisa julgada, alegam que a mesma não pode ser admitida sob o mero argumento de injustiça, devendo estar restrita às hipóteses de sentenças inconstitucionais transitadas em julgado.

\footnotetext{
${ }^{18}$ DINAMARCO, Cândido Rangel, op. cit., p. 227.

19 “A grave injustiça não deve prevalecer em época nenhuma, mesmo protegida pelo manto da coisa julgada, em um regime democrático, porque ela afronta a soberania da proteção da cidadania.” DELGADO, José Augusto. Efeitos da coisa julgada e os princípios constitucionais. In: NASCIMENTO, Carlos Valder do (Coord.), op. cit., p. 54.

${ }^{20}$ Maria Berenice Dias defende que a revisão do encargo alimentar fixado será sempre possível quando houver o desatendimento do trinômio proporcionalidade-possibilidade-necessidade. Assim, disserta a doutrinadora: "Mesmo que não tenha ocorrido alteração, quer das possibilidades do alimentante, quer das necessidades do alimentado, possível a adequação a qualquer tempo. Essa é a única forma de impedir a perpetuação de flagrantes injustiças. Ora, se fixado o montante dos alimentos sem que, por exemplo, saiba o credor dos reais ganhos do devedor, ao tomar conhecimento de que o valor estabelecido desatende ao princípio da proporcionalidade, cabe buscar a redefinição, sem que a pretensão esbarre na coisa julgada.” DIAS, Maria Berenice. Manual de Direitos das Famílias. 5. ed. São Paulo: Editora Revista dos Tribunais, 2009, p. 531.

${ }^{21}$ Cf. CÂMARA, Alexandre Freitas, op. cit., p. 195.

22 "A tese que sustentamos, todavia, não se ampara apenas e singelamente na injustiça da sentença. O que pretendemos é que há um tipo de injustiça muito mais grave do que o decorrente da ilegalidade ou da contravenção ética. Trata-se da vulneração pela sentença de algum preceito ou mandamento constitucional.” THEODORO JÚNIOR, Humberto; FARIA, Juliana Cordeiro de, op. cit., p. 108.
} 
Na terceira corrente, enquadramos o doutrinador Cândido Rangel Dinamarco ${ }^{23}$, segundo o qual admitir que qualquer inconstitucionalidade constitui motivo suficiente para ensejar a relativização da coisa julgada permite uma absoluta vulnerabilidade do instituto, uma vez que não leva em consideração a ponderação entre o valor segurança e o valor transgredido em cada caso concreto. O autor caracteriza esta postura como puramente dogmática, sob o argumento de que ela consiste, tão somente, em comparar hierarquicamente as leis e as decisões com a Constituição Federal.

Desse modo, Cândido Rangel Dinamarco defende que, a princípio, ainda que a decisão seja inconstitucional, a coisa julgada deve prevalecer, porque ela também é uma garantia constitucional. Percebe-se, portanto, que o autor recorre-se à técnica da ponderação e ao princípio da proporcionalidade, a fim de admitir a relativização da coisa julgada inconstitucional somente se o valor transgredido na decisão judicial for de nível mais elevado que a segurança jurídica.

\subsection{Críticas à teoria da relativização}

Os doutrinadores que não admitem a relativização da coisa julgada inconstitucional defendem que o referido instituto processual é uma garantia imprescindível em um Estado Democrático de Direito, tutelando a segurança das relações jurídicas e a própria inafastabilidade da jurisdição. ${ }^{24}$ Ademais, sustentam que a justiça é conceito subjetivo, de modo que, sob o argumento de extrema injustiça inconstitucional, as decisões tornar-se-iam suscetíveis a sucessivas relativizações, eternizando-se as lides e aniquilando o próprio instituto da coisa julgada. ${ }^{25}$

Luiz Guilherme Marinoni adverte acerca da ausência de garantia de que a segunda decisão - proferida em substituição à primeira, que teve a sua coisa julgada relativizada estará em conformidade com as regras do ordenamento jurídico e com os ditames da justiça. ${ }^{26}$ Outros doutrinadores, conquanto não sejam totalmente desfavoráveis à relativização, criticam

\footnotetext{
${ }^{23}$ Cf. DINAMARCO, Cândido Rangel, op. cit., p. 241.

${ }^{24}$ Cf. MARINONI, Luiz Guilherme. Relativizar a coisa julgada material? Revista dos Tribunais, São Paulo, ano 93, v. 830, p. 55-73, dezembro de 2004 e GOÉS, Gisele Santos Fernandes, op. cit., p. 254.

${ }^{25}$ Cf. DIDIER JÚNIOR, Fredie; BRAGA, Paula Sarno; OLIVEIRA, Rafael. Curso de Direito Processual Civil. 4. ed. Savador: Jus Podivm, 2009, p. 443; MARINONI, Luiz Guilherme, op. cit., p. 71 e GOÉS, Gisele Santos Fernandes, op. cit., p. 254 e s.

${ }^{26}$ Cf. MARINONI, Luiz Guilherme, op. cit., p. 58.
} 
certas hipóteses e argumentos apresentados para justificá-la, afirmando que eles constituem excepcionalidades no ordenamento jurídico. ${ }^{27}$

Embora seja inegável a relevância do movimento de relativização da coisa julgada, tendo em vista que ele se destina à concretização do ideal do justo, as diversas críticas que lhe são direcionadas demonstram que é preciso agir com parcimônia. Desse modo, a pretexto de se concretizar um ideal de justiça, não se pode colocar em risco os instrumentos garantidores do devido processo legal. Em conformidade com referido pensamento, José Carlos Barbosa Moreira tece a seguinte advertência: "Há, porém, um momento em que à preocupação de fazer justiça se sobrepõe a de não deixar que o litígio se eternize.”28

\section{DO VÍCIO DA INCONSTITUCIONALIDADE}

\subsection{Análise do vício da inconstitucionalidade sob a ótica da teoria dos atos jurídicos}

Há diferentes apontamentos acerca do vício da inconstitucionalidade, divergindo a doutrina se o mesmo atinge o plano da existência ${ }^{29}$, da validade $^{30}$ ou da eficácia ${ }^{31}$ das sentenças por ele contaminadas. Por serem os pronunciamentos judiciais categoria dos atos jurídicos, a fim de desvendar em qual plano situa-se o vício da inconstitucionalidade, valemonos da teoria geral dos atos jurídicos. ${ }^{32}$

Desse modo, entendemos que a decisão judicial, mesmo quando inconstitucional, é existente, pois contém todos os requisitos tecnicamente indispensáveis à sua finalidade prática. Assim, para o presente artigo, a tese que se revela mais adequada é a que situa o vício

\footnotetext{
27 "Reconheça-se desde logo que os exemplos são, por assim dizer (sem ironia), pitorescos. Outra questão é saber se existe alguma probabilidade de que hipóteses tão esdrúxulas se concretizem no mundo real." MOREIRA, José Carlos Barbosa, op. cit, p. 250. Em conformidade é a lição de Ovídio A. Baptista da Silva, o qual afirma que relativizar a coisa julgada sob o fundamento de transgressão a princípio é questioná-la com base em premissa impalpável e difícil de ser visualizada, pois princípios constituem normas abertas que obedecem a uma escala de otimização. Cf. SILVA, Ovídio A. Baptista da. Coisa Julgada Relativa? Revista Jurídica, São Paulo, n. 316, p. 7-18, fev. 2004.

${ }^{28}$ MOREIRA, José Carlos Barbosa, op. cit., p. 243.

${ }^{29}$ Cf. WAMBIER, Teresa Arruda Alvim; MEDINA, José Miguel Garcia. O Dogma da Coisa Julgada: hipóteses de relativização, São Paulo: Editora Revista dos Tribunais, 2003, p. 354-358.

${ }^{30}$ Cf. THEODORO JÚNIOR, Humberto; FARIA, Juliana Cordeiro de, op. cit, p. 89-90.

${ }^{31}$ Cf. DINAMARCO, Cândido Rangel, op. cit., p. 248.

${ }^{32}$ Nesse ponto, torna-se relevante a seguinte observação, formulada pelo professor Adroaldo F. Fabrício, no que tange à teoria das nulidades: "Quando se trata da validade de atos processuais, e em particular da sentença, o esquema classificatório dos vícios fixado pela doutrina tradicional, se aproveitável, tem de ser tomado com cautela, tendo-se em cuidadosa linha de conta a especificidade daqueles atos e sobretudo a eficácia sanatória peculiaríssima da coisa julgada.” FABRÍCIO, Adroaldo Furtado. Réu revel não citado, querela nullitatis e ação rescisória. Revista de Processo, São Paulo, n. 48, p. 27-44, 1987.
} 
da inconstitucionalidade no plano da validade da decisão judicial, tornando-a nula, assim como ocorre com os atos legislativos inconstitucionais. Em conformidade, é a lição de Luís Roberto Barroso:

\begin{abstract}
A inconstitucionalidade, portanto, constitui vício aferido no plano da validade. Reconhecida a invalidade, tal fato se projeta para o plano seguinte, que é o da eficácia: norma inconstitucional não deve ser aplicada. ${ }^{33}$
\end{abstract}

Nos termos dos ensinamentos supracitados, conclui-se que a decisão judicial eivada do vício da inconstitucionalidade é nula e que o reconhecimento de tal invalidade projeta-se para o plano da eficácia, de modo que deverão ser desconstituídos os efeitos produzidos. Frisa-se, nesse ponto, que a decisão judicial, por ter produzido efeitos, deverá ser desconstituída. ${ }^{34}$ Não basta, pois, desconsiderá-la, como têm admitido alguns doutrinadores, que defendem a simples possibilidade de ajuizamento de uma nova ação.

\title{
3.2 Vício da inconstitucionalidade e eficácia sanatória geral da coisa julgada
}

Um questionamento relevante que permeia a análise do vício da inconstitucionalidade é a possibilidade de ser ele sanado pela eficácia sanatória geral da coisa julgada. Acerca do referido questionamento, esclarecedores são os ensinamentos de Enrico Tullio Liebman, o qual adverte que há vícios maiores e essenciais que sobrevivem à coisa julgada, como, por exemplo, o vício da inconstitucionalidade. ${ }^{35}$

Nesse contexto, cumpre relembrar que as nulidades que viciam o processo como um todo, inclusive o pronunciamento judicial, em regra, ou são sanadas por meio da eficácia sanatória da coisa julgada ou transformam-se em hipóteses de rescindibilidade. ${ }^{36}$ Há, contudo, uma hipótese em que o vício não é sanado por meio da eficácia sanatória geral da coisa julgada, tampouco pelo decurso do prazo decadencial de dois anos previsto para o

\footnotetext{
${ }^{33}$ BARROSO, Luís Roberto, op. cit., p. 14-15.

34 “[...] o ato processual nulo produz efeitos, se e enquanto o juiz não o desconstituir [...]” ASSIS, Araken de. Coisa Julgada inconstitucional. In: NASCIMENTO, Carlos Valder do (Coord.), op. cit., p. 217.

${ }^{35}$ LIEBMAN, Enrico Tullio apud THEODORO JÚNIOR, Humberto; FARIA, Juliana Cordeiro de, op. cit., p. 109.

36 "Com a passagem em julgado, em regra, as nulidades absolutas e relativas, propriamente ditas, ou simples anulabilidades, ou são de todo apagadas ou assumem a feição de mera rescindibilidade” FABRÍCIO, Adroaldo Furtado, op. cit., p. 27-44.
} 
ajuizamento da ação rescisória: é o caso da citação irregular somada à revelia, vício esse que, segundo doutrina e jurisprudência majoritárias, enseja o cabimento da querela nullitatis. ${ }^{37}$

Assim, tendo em vista que a eficácia sanatória da coisa julgada não sana determinadas irregularidades que se transformam em hipóteses de rescindibilidade, existindo, ainda, a hipótese de citação irregular, a qual não é sanada nem mesmo com o decurso do prazo da ação rescisória, entendemos que referida eficácia, com maior razão, também não sana o vício da inconstitucionalidade, porquanto este, além de ensejar nulidade absoluta, é um vício de extrema gravidade. Desse modo, entendemos que o vício da inconstitucionalidade deve ser enquadrado na categoria dos denominados "vícios transrescisórios”38, uma vez que ele transcende à coisa julgada e ao prazo bienal da ação rescisória.

\section{INSTRUMENTOS DA RELATIVIZAÇÃO}

\subsection{Instrumentos da relativização típica}

No que diz respeito à relativização típica ${ }^{39}$ da coisa julgada inconstitucional, os instrumentos que se destinam a tal propósito são a ação rescisória e a impugnação de sentença inconstitucional previstos nos artigos 475-L, parágrafo $1^{\circ}$, e 741 , parágrafo único, do CPC (Código de Processo Civil).

A ação rescisória é uma ação autônoma de impugnação da decisão de mérito, que deve ser ajuizada dentro do prazo decadencial de dois anos contados a partir do trânsito em julgado, desde que verificada alguma hipótese prevista no artigo 485, do CPC. ${ }^{40}$ As hipóteses

\footnotetext{
37 “A despeito da disciplina geral, a lei infraconstitucional, que outorga, ou não, a eficácia de coisa julgada a determinados provimentos do juiz, às vezes erige determinado vício essencial, porque ele parece suficientemente grave e relevante, de modo a receber tratamento privilegiado e diferente, à condição de defeito imune a quaisquer preclusões, incluindo a mais expressiva e maior delas: a coisa julgada. Na hipótese do inc. I do art. 741, o vício da citação sobrevive ao trânsito em julgado do título [...] Põe-se de acordo a doutrina que, no art. 741, I, subsiste a vetusta querela nullitatis romana.” ASSIS, Araken de, op. cit., p. 218. Nesse mesmo sentido, é o posicionamento de Adroaldo Furtado Fabrício. Cf. FABRÍCIO, Adroaldo Furtado, op. cit., p. 27-44.

${ }^{38}$ De acordo com Tesheiner, transrescisórios são "vícios correspondentes a pressupostos cuja falta autoriza a declaração da inexistência ou ineficácia da sentença, ou a decretação de sua nulidade, ainda que decorrido o prazo para a propositura da ação rescisóra.” TESHEINER, José Maria Rosa. Pressupostos processuais e nulidades no processo civil. São Paulo: Saraiva, 2000, p. 283-284.

39 Conforme já assinalado na introdução, há na doutrina quem estabeleça diferenciação entre as expressões “relativização típica” e “relativização atípica”. Assim, a primeira expressão é utilizada tão somente para os casos em que a coisa julgada pode ser relativizada com base em instrumentos legalmente previstos. Já a segunda é utilizada para referir-se a todas as hipóteses não tipificadas no ordenamento jurídico brasileiro.

${ }^{40}$ Excepcionalmente, tem-se admitido o ajuizamento da ação rescisória em face de decisão que não versou sobre matéria de mérito, desde que sejam juridicamente impossíveis a propositura de outra demanda idêntica e a interposição de recurso. Nesse sentido, é a lição do professor Bernardo Pimentel, o qual cita como exemplo a
} 
de rescindibilidade previstas nos nove incisos do artigo 485, do CPC, constituem um rol taxativo, não se admitindo interpretação extensiva.

Os artigos 475-L, parágrafo $1^{\circ}$, e 741 , parágrafo único, do CPC, disciplinam, respectivamente, a impugnação ao cumprimento de sentença e os embargos à execução contra a Fazenda Pública. Eles possuem redação idêntica e dispõem acerca da inexigibilidade do título judicial fundado em lei ou ato normativo declarados inconstitucionais pelo STF, ou fundado em aplicação ou interpretação da lei ou ato normativo tidas pelo STF como incompatíveis com a Constituição Federal. Tais dispositivos são exemplos expressos do início do movimento de relativização da coisa julgada.

Convém registrar, no entanto, que na hipótese dos artigos 475-L, parágrafo $1^{\circ}$, e 741 , parágrafo único, os provimentos judiciais permanecerão íntegros. Com efeito, nesses casos, o juízo de inconstitucionalidade atuará no plano da eficácia, desfazendo a eficácia da coisa julgada de forma retroativa e apagando o efeito executivo da condenação, de forma a tornar inadmissível a execução. ${ }^{41}$

Essa solução jurídica adotada pelo ordenamento é alvo de muitas críticas. Em primeiro lugar, porque referidos dispositivos não prevêem a desconstituição dos títulos judiciais inconstitucionais, estabelecendo, tão somente, a sua inexigibilidade. Em segundo lugar, porque os dispositivos não ressalvam a inconstitucionalidade superveniente ao trânsito em julgado, razão pela qual, a exemplo do que ocorre com os incisos I, dos referidos dispositivos, tem-se permitido que a inexigibilidade seja alegada a qualquer momento. ${ }^{42}$ Em terceiro lugar, porque permitem que um juiz de primeiro grau determine a inexigibilidade de decisão proferida por órgão superior. Em quinto lugar, porque tais dispositivos não abarcam as decisões satisfativas, as quais dispensam futura execução, como ocorre com as decisões declaratórias. $^{43}$

hipótese em que o juiz de primeiro grau extingue o processo sem julgamento do mérito, com base no art. 267, V, do CPC. Nesse caso, decorrido in albis o prazo recursal, se o autor constatar que a referida sentença está contaminada com vício arrolado no art. 485, tendo em vista a impossibilidade de se ajuizar nova ação (CPC, 268), a única solução é o ajuizamento de ação rescisória, embora se trate de sentença terminativa. Cf. PIMENTEL SOUZA, Bernardo. Introdução aos recursos cíveis e à ação rescisória. 7. ed. São Paulo: Saraiva, 2010, p. 619. Cumpre ainda ressaltar que o trânsito em julgado da decisão de mérito só ocorre após o último julgamento proferido no processo, ainda que esse último julgamento não tenha versado sobre o mérito da causa. Cf. Ibidem, p. 58.

${ }^{41}$ Cf. ASSIS, Araken de, op. cit., p. 221.

42 “A qualquer momento, pronunciada a inconstitucionalidade da lei ou do ato normativo em que se baseou o pronunciamento judicial, desaparecerá a eficácia do art. 467. E isto se verificará ainda que a Corte Constitucional se manifeste após o prazo de dois anos da rescisória (art. 495).” ASSIS, Araken de, op. cit., p. 222.

43 Cf. GOMES, Magno Federici; COHEN, Ricardo Moraes. Relativização da Coisa Julgada: Teorias, Controvérsias, Dilemas e Solução. Revista IOB de Direito Civil e Processual Civil, São Paulo, ano IX, n. 53, p. 83-101, maio-jun/2008. 


\subsection{Instrumentos da relativização atípica}

Entre os doutrinadores que admitem a relativização atípica da coisa julgada, surge a discussão de qual seria o instrumento processual adequado para tal fim. Nesse sentido, para a maioria deles, a desconstituição da coisa julgada inconstitucional independe de muita formalidade, podendo efetivar-se através de ação rescisória; embargos à execução; exceção de pré-executividade; querela nullitatis; incidentalmente, em uma ação ordinária tendente a reexaminar a mesma relação jurídica; e, até mesmo, de ofício. ${ }^{44}$

Uma crítica consistente direcionada à relativização atípica é exatamente a ausência de parâmetros na definição dos instrumentos viáveis para concretizá-la. Isso porque, referidos instrumentos podem gerar uma grave incompatibilidade lógica no sistema: a possibilidade de qualquer juiz ou tribunal desrespeitar a coisa julgada decorrente de decisão proferida por outro órgão judiciário, de igual ou superior hierarquia. ${ }^{45}$

\subsection{Análise sob a ótica do ordenamento de lege lata}

Alguns doutrinadores defendem que não há que se falar em meios atípicos de relativização, pois o ordenamento jurídico brasileiro de lege lata permite a desconstituição da coisa julgada que acoberta a sentença inconstitucional. Nesse sentido, o doutrinador Fredie Didier defende que o direito positivo brasileiro já solucionou o problema da relativização da coisa julgada inconstitucional de duas maneiras: com a possibilidade de ação rescisória fundamentada na violação literal de lei, prevista no artigo 485, inciso V, do CPC, juntamente com a mitigação do rigor da súmula $\mathrm{n}^{\circ} 343$ do STF, e com a inexigibilidade do título judicial contrário à Constituição Federal prevista nos artigos 475-L, parágrafo $1^{\circ}$, e 741 , parágrafo único, do CPC. ${ }^{46}$

De acordo com Fredie Didier, a sentença de mérito transitada em julgado que viola a Constituição Federal pode ser desconstituída com fundamento no inciso V, do artigo 485, do CPC, o qual dispõe sobre a hipótese de violação literal à disposição de lei. Cumpre registrar

\footnotetext{
${ }^{44}$ Cf. THEODORO JÚNIOR, Humberto; FARIA, Juliana Cordeiro de, op. cit., p. 96-97 e CÂMARA, Alexandre Freitas, op. cit., p. 196-200.

${ }^{45}$ Cf. TESHEINER, José Maria Rosa. Relativização da Coisa Julgada. Revista do Ministério Público/RS, Porto Alegre, n. 47, p. 104-114, 2002.

${ }^{46}$ Cf. DIDIER JÚNIOR, Fredie; BRAGA, Paula Sarno; OLIVEIRA, Rafael, op. cit., p. 443.
} 
que a acepção do termo "lei” no referido dispositivo é ampla, abrangendo, inclusive, a Constituição Federal. $^{47}$

O vocábulo "literal” inserto no inciso V, do artigo 485, revela a exigência de que a afronta deve ser tamanha que contrarie a lei em sua literalidade, ou seja, se o texto legal der ensejo a mais de uma interpretação, não é possível desconstituir o julgado com fundamento em qualquer uma das interpretações plausíveis. Essa é a orientação da súmula n. 343 do STF: “Não cabe ação rescisória por ofensa a literal disposição de lei, quando a decisão rescindenda se tiver baseado em texto legal de interpretação controvertida nos tribunais.”

No entanto, no que tange à violação a preceito constitucional, o próprio STF tem decidido ser inaplicável o referido enunciado sumular. ${ }^{48}$ Prevalece, assim, o entendimento consubstanciado na súmula n. 63 do TRF (Tribunal Regional Federal) da $4^{\text {a }}$ Região: "Não é aplicável a Súmula 343 do STF nas ações rescisórias versando matéria constitucional”. Desse modo, tendo em vista que, não raras vezes, o mesmo dispositivo constitucional dá ensejo a interpretações variadas, ainda assim será possível o ajuizamento de ação rescisória com base no inciso $\mathrm{V}$, do artigo 485, do CPC.

Ao se mitigar a aplicabilidade da súmula n. 343 no que tange às matérias constitucionais, afasta-se o requisito da ofensa literal, instituindo-se, na verdade, uma cláusula geral de revisão da coisa julgada inconstitucional. Portanto, nota-se que a conjugação do inciso V, do art. 485, do CPC, com a mitigação da súmula 343 do STF, efetivamente cria uma hipótese de rescisão de toda e qualquer decisão de mérito transitada em julgado que viola diretamente a Constituição Federal.

\subsection{Proposta de lege ferenda}

Não obstante tenha o ordenamento jurídico brasileiro criado uma cláusula geral de revisão das sentenças inconstitucionais transitadas em julgado que violam diretamente a Constituição Federal, o problema persiste após o transcurso do prazo de dois anos, ou seja, em relação à coisa soberanamente julgada. ${ }^{49}$

Ademais, em relação às decisões que violam indiretamente a Constituição Federal, previstas nos artigos 475-L, parágrafo $1^{\circ}$, e 741, parágrafo único, embora o ordenamento

\footnotetext{
${ }^{47}$ Cf. PIMENTEL SOUZA, Bernardo, op. cit., p. 628-629.

${ }^{48}$ Cf. BRASIL. Supremo Tribunal Federal. Ag. Reg. no RE 567.765/SP. Recorrente: Marcos A. Camilo. Recorrido: Banco Bradesco S/A. Relator: Rosa Weber. Brasília, 16 de abril de 2013.

${ }^{49}$ A expressão “Coisa soberanamente julgada” refere-se à decisão transitada em julgado que não pode mais ser revista por meio da ação rescisória, por já ter transcorrido o prazo decadencial de dois anos.
} 
jurídico tenha criado uma forma de relativização, permitindo a inexigibilidade do título judicial, essa solução, conforme já demonstrado, é alvo de muitas críticas.

Assim, com o intuito de uniformizar o regramento legal acerca da sentença inconstitucional e dirimir as incongruências que permeiam o ordenamento atual, o presente trabalho propõe uma alteração legislativa no inciso V, do artigo 485, do CPC, de modo que o mesmo, que já abrange as hipóteses de violação direta à Constituição Federal, passe a alcançar as hipóteses de violação indireta. Dessa forma, não haveria razão para a subsistência dos artigos 475-L, parágrafo $1^{\circ}$, e 741, parágrafo único, no ordenamento jurídico.

Além de se concentrar no inciso V, do artigo 485, do CPC, as hipóteses de violação direta e indireta à Constituição Federal, propõe-se que se estabeleça, em conformidade com os ensinamentos de Cândido Rangel Dinamarco, a necessidade de ponderação diante do caso concreto, a qual deverá ser efetivada pelo tribunal competente no momento de apreciação da ação rescisória. Somente se o valor constitucional violado for superior ao valor segurança jurídica é que será permitida a desconstituição da coisa julgada.

Tendo em vista que no caso de violação indireta à Constituição Federal já se tem permitido a alegação de inexigibilidade do título a qualquer momento ${ }^{50}$, com muito mais razão deverá ser abolida a exigência de prazo para a hipótese de violação direta. Tal fato, somado à gravidade do vício da inconstitucionalidade e à inexistência de prazo para o reconhecimento da inconstitucionalidade dos atos legislativos, leva-nos a defender a abolição do prazo decadencial de dois anos em todos os casos de violação à Constituição Federal. Ressalta-se, no entanto, que a abolição do prazo abrangerá apenas as hipóteses de inconstitucionalidade, persistindo a necessidade de se respeitar o biênio nos casos de mera ilegalidade.

A abolição do prazo decadencial, embora, em um primeiro momento, seja um indicativo de violação à segurança jurídica, podendo ocasionar o aumento do número de demandas rescisórias, constitui uma mudança necessária para se evitar a própria desconsideração da coisa julgada.

Nesse sentido, faz-se necessário registrar que persistirá a necessidade de ajuizamento da ação rescisória, de modo que não será possível desconstituir a coisa julgada por qualquer meio processual. Ademais, sendo a referida ação de competência originária dos tribunais, afasta-se a possibilidade de violação à hierarquia das decisões judiciais, não sendo possível

\footnotetext{
50 "Ressalta-se que o uso da ação autônoma não se vincula à observância do prazo dos embargos (art. 738). É lícito ao vencido empregá-lo após o desaparecimento da oportunidade para embargar.” ASSIS, Araken de, op. cit., p. 226.
} 
que um magistrado possa desconstituir coisa julgada de decisão proferida por juízo de instância superior ou reconhecer a inexigibilidade da referida decisão.

Por derradeiro, ressaltamos que o próprio regramento legal da ação rescisória prevê mecanismos capazes de evitar o ajuizamento de ações manifestamente inadmissíveis e improcedentes, como, por exemplo, a necessidade de depósito equivalente a 5\% (cinco por cento) do valor da causa, conforme prevê o artigo 488, II, do CPC. ${ }^{51}$

\section{CONSIDERAÇÕES FINAIS}

O fato de ser a coisa julgada um direito fundamental e, por conseguinte, cláusula pétrea, não significa que ela seja absoluta e imune a quaisquer revisões. Por outro lado, é preciso parcimônia em relação ao desejo de mudar, sob pena de se aniquilar garantias fundamentais ao Estado Democrático de Direito.

O presente artigo prestigiou a doutrina que enquadra o vício da inconstitucionalidade no plano da validade da decisão e defendeu o seu enquadramento na categoria dos vícios transrescisórios, sendo, pois, necessário encontrar um instrumento hábil para desconstituir a coisa julgada inconstitucional dele resultante.

Para isso, antes de se apresentar qualquer proposta de lege ferenda, procurou-se buscar uma solução nos instrumentos legalmente previstos para a revisão da coisa julgada. Desse modo, verificou-se que o ordenamento jurídico brasileiro, de lege lata, permite a revisão de sentenças inconstitucionais transitadas em julgado.

No que diz respeito à decisão que viola indiretamente a Constituição Federal, o CPC expressamente criou uma hipótese de relativização da coisa julgada, conforme se vislumbra nos artigos 475-L, parágrafo $1^{\circ}$, e 741 , parágrafo único. No que diz respeito à violação direta da Constituição Federal, nota-se que a conjugação do artigo 485, V, do CPC, com o afastamento do enunciado n. 343 da súmula do STF, permite a desconstituição da decisão acobertada pela coisa julgada inconstitucional.

No entanto, foi constatado que o ordenamento jurídico de lege lata incorre em diversas incongruências, que são alvos de muitas críticas. Desse modo, a fim de contribuir para o adequado tratamento das sentenças inconstitucionais transitadas em julgado, apresentou-se

\footnotetext{
${ }^{51}$ Os doutrinadores Alexandre Freitas Câmara e Sérgio Gilberto Porto também formularam, em relação ao presente tema, propostas de lege ferenda que englobam a revisão das hipóteses de cabimento da ação rescisória e do prazo decadencial de dois anos. Cf. CÂMARA, Alexandre Freitas, op. cit., p. 201 e PORTO, Sérgio Gilberto. Cidadania processual e relativização da coisa julgada. Revista Síntese de Direito Civil e Processual Civil, Porto Alegre, v. 4, n 21, 5-13, jan./fev. 2003.
} 
uma proposta de lege ferenda que prevê algumas alterações no instituto da ação rescisória. Pretende-se, a partir da referida proposta, evitar a perpetuação de injustiças, com a cautela de não se promover mudanças desnecessárias e de garantir a observância do devido processo legal, prestigiando, igualmente, a segurança jurídica.

\section{REFERÊNCIAS}

ASSIS, Araken de. Coisa Julgada inconstitucional. In: NASCIMENTO, Carlos Valder do (Coord.). Coisa julgada inconstitucional. 4. ed. Rio de Janeiro: América Jurídica, 2003.

BARROSO, Luís Roberto. O controle de constitucionalidade no direito brasileiro. 4. ed. São Paulo: Saraiva, 2009.

CÂMARA, Alexandre Freitas. Relativização da coisa julgada material. In: NASCIMENTO, Carlos Valder do (Coord.). Coisa julgada inconstitucional. 4. ed. Rio de Janeiro: América Jurídica, 2003.

DELGADO, José Augusto. Efeitos da coisa julgada e os princípios constitucionais. In: NASCIMENTO, Carlos Valder do (Coord.). Coisa julgada inconstitucional. 4. ed. Rio de Janeiro: América Jurídica, 2003.

DIAS, Maria Berenice. Manual de Direitos das Famílias. 5. ed. São Paulo: Editora Revista dos Tribunais, 2009.

DIDIER JÚNIOR, Fredie; BRAGA, Paula Sarno; OLIVEIRA, Rafael. Curso de Direito Processual Civil. 4. ed. Savador: Jus Podivm, 2009.

DINAMARCO, Cândido Rangel. A Nova Era do Processo Civil. São Paulo: Malheiros, 2003.

FABRÍCIO, Adroaldo Furtado. Réu revel não citado, querela nullitatis e ação rescisória. Revista de Processo, São Paulo, n. 48, p. 27-44, 1987.

GOÉS, Gisele Santos Fernandes. A “Relativização" da Coisa Julgada: exame crítico (exposição de um ponto de vista contrário). Revista de Processo, São Paulo, ano 31, n. 135, p. 249-265, maio de 2006.

GOMES, Magno Federici; COHEN, Ricardo Moraes. Relativização da Coisa Julgada: Teorias, Controvérsias, Dilemas e Solução. Revista IOB de Direito Civil e Processual Civil, São Paulo, ano IX, n. 53, p. 83-101, maio-jun/2008.

KELSEN, Hans. Teoria Pura do Direito. 6. ed. São Paulo: Martins Fontes, 1998.

LIMA, Paulo Roberto de Oliveira. Contribuição à teoria da coisa julgada. São Paulo: RT, 1997. 
MARINONI, Luiz Guilherme. Relativizar a coisa julgada material? Revista dos Tribunais. São Paulo, ano 93, v. 830, p. 55-73, dez. 2004.

MITIDIERO, Daniel. Colaboração no processo civil: pressupostos sociais, lógicos e éticos. 2. ed. São Paulo: Editora Revista dos Tribunais, 2011.

MOREIRA, José Carlos Barbosa. Temas de direito processual civil (nona série). São Paulo: Saraiva, 2007.

OTERO, Paulo. Ensaio sobre o caso julgado inconstitucional. Lisboa: Lex, 1993.

PIMENTEL SOUZA, Bernardo. Introdução aos recursos cíveis e à ação rescisória. 7. ed. São Paulo: Saraiva, 2010.

PORTO, Sérgio Gilberto. Cidadania processual e relativização da coisa julgada. Revista Síntese de Direito Civil e Processual Civil, Porto Alegre, v. 4, n. 21, p. 5-13, jan./fev. 2003.

SILVA, Ovídio A. Baptista da. Coisa Julgada Relativa? Revista Jurídica, São Paulo, n. 316, p. 7-18, fev. 2004.

TESHEINER, José Maria Rosa. Pressupostos processuais e nulidades no processo civil. São Paulo: Saraiva, 2000.

Relativização da Coisa Julgada. Revista do Ministério Público/RS, Porto Alegre, n. 47, p. 104-114, 2002.

THEODORO JÚNIOR, Humberto; FARIA, Juliana Cordeiro de. A coisa julgada inconstitucional e os instrumentos processuais para o seu controle. In: NASCIMENTO, Carlos Valder do (Coord.). Coisa julgada inconstitucional. 4. ed. Rio de Janeiro: América Jurídica, 2003.

WAMBIER, Teresa Arruda Alvim; MEDINA, José Miguel Garcia. O Dogma da Coisa Julgada: Hipóteses de Relativização. São Paulo: Editora Revista dos Tribunais, 2003. 